\title{
SAMA'-BAJAU INFLUENCES IN MAKIANG MUSICAL CULTURE
}

\author{
Jacqueline Pugh-Kitingan \\ Universiti Malaysia Sabah \\ (jacquie@ums.edu.my) \\ DOI: https://doi.org/10.22452/brj.sp2019no1.10
}

\begin{abstract}
Situated along upper portions of the Kinabatangan River of eastern Sabah, from beyond Tongod upriver to below Kota Kinabatangan downstream, the Makiang speak a dialect of the Upper Kinabatangan language, one of five languages in Sabah's indigenous Paitanic Family of Languages. Known as the Milian in the Makiang dialect, the Kinabatangan is said to be Sabah's longest river. Over hundreds of years, it has provided a link between indigenous peoples in its upper reaches and east coast maritime peoples. The river has enabled trade between the many different interior communities with coastal peoples, leading to the diffusion of objects, ideas and practices. This paper discusses instruments and genres of Makiang group music that suggest evidence of diffusion from Sama'-Bajau and also Suluk musical practices, including the morunsai vocal dance genre as well as the performances of the ensembles sampasang no gabang and sampasang no kulintangan. It illustrates evidence for the processes of cultural convergences through which east coast Sama'-Bajau musical practices that have been absorbed into interior cultures and transformed over time.
\end{abstract}

Keywords: group music, morunsai, sampasang no gabang, sampasang no kulintangan, Makiang, Paitanic language family, Sama'-Bajau, eastern Sabah, diffusion, cultural convergence

\section{Introduction}

Sabah's geography features major river systems that flow from the mountainous backbone of the interior and meander across extensive alluvial plains to the coast. Rivers across eastern Sabah include the Paitan, Labuk (Sugut), Kinabatangan, and the Segama. For thousands of years, these rivers have supported various indigenous cultures including Dusunic and Paitanic peoples, as well as speakers of Ida'an, Bega'ak and Subpan dialects of the Ida'an language, and some very remote inland Murutic villages.

The Kinabatangan River, called Milian in the Upper Kinabatangan language, is said to be Sabah's longest river (Vaz \& Payne, 1997/1998, p. 5). Many diverse communities live along its multitude of tributaries. The Tangara Murut, who speak a dialect of Bookan Murut, reside in its remote upper reaches. Various Paitanic groups 
including speakers of the Lobu (Lobuu) dialects Lobu and Rumanau, and dialects of the Upper Kinabatangan language such as Kalabuan (Kolobuan), Makiang, Sinabu', Sinarupa and Kuamut, are found in the upper Kinabatangan River area but downstream from the Tangara. Sukang and Mangkaak, subgroups of the LabukKinabatangan Dusun, also live along parts of the Kinabatangan River, while some Ida'an villages are located further downstream around Bilit and Sukau (King, 1984/1997, pp. 139-153; “Malaysia: Sabah”, 2016). Outsiders often collectively label these diverse peoples Orang Sungai ("river people"), a gloss that ignores the cultural uniqueness of each group.

Like other eastern rivers, the Kinabatangan has served as a conduit linking upriver peoples with coastal and maritime communities such as the Sama'-Bajau and the Suluk (Taosug). In former times, brassware, gongs, ceramic jars and other objects were traded up the river in exchange for forest products and other resources from the interior. Cultural contacts due to trade also saw the diffusion of musical elements from coastal communities into interior societies in eastern Sabah.

Kartomi (1994/2008, pp. ix-x) uses the term 'cultural convergence,' which is a similar concept 'language convergence' (Pallesan, 1985), to describe processes that include both diffusion of minor traits and major creative transformations of styles, including principles of musical organisation, that have resulted from contacts between diverse cultures over a period of time. She describes 'cultural collision', on the other hand, as a clash between diverse cultures, whereby a dominant society may suppress the music-culture of a minority group or, conversely, a smaller group may reject the music of a larger one. Cultural collisions often result from war.

This paper will discuss the nature of cultural convergence, due to riverine trade from east coastal maritime communities such as the Sama'-Bajau and the Suluk, which has influenced the music-culture of the Makiang. In looking at frequently performed genres of Makiang vocal and instrumental music, it seeks to answer the following questions. How has cultural convergence affected Makiang musical culture? Has it resulted in small-scale diffusion of elements or major musical transformations?

\section{The Makiang}

The Makiang live along upper sections of the Kinabatangan River in the Tongod and Kinabatangan Districts, from beyond Tongod Town upriver to below the town of Kota Kinabatangan downstream. As mentioned above, they speak a dialect of the Upper Kinabatangan language, which is one of five languages in Sabah's indigenous Paitanic Family of Languages and one of two in the area of the Upper Kinabatangan River, the other being Lobu (Lyman, 1990/1991, p. 111). Each river tributary supports extended villages, that formerly consisted of series of longhouses (waloy no bininatang) along the riverbanks. A massive smallpox epidemic across northern Borneo from 1904 to 1905, 
the Japanese occupation in World War II, and the coming of the British colonial administration after the War are each thought to have contributed to the decline of longhouses, and today villages are normally composed of single family dwellings.

Traditionally, the Makang socioeconomic system revolved around the cultivation of dry rice and riverine fishing, supplemented with hunted game from the forests. Cash cropping has developed more recently. The timber industry boom of the 1970s to 1980s depleted many forested areas, depriving people of closely available traditional sources of protein from hunted game. This has been followed in recent years by the planting of huge oil palm estates with the construction of oil mills that have polluted many of the river tributaries and consumed much of the land that was formerly forest. Today, many Makiang are engaged in farming and cash cropping or work on oil palm estates, while some serve in the business and professional sectors.

The Makiang are an aecephalous society with bilateral kinship and gender balance. Marriage is exogamous as far as third cousins, and is initiated through a muilug, a long discussion between the parents and other kin of the potential partners, chaired by a go-between. The muilug is held to ensure that the future partners are not closely related and to determine the amount of buru' or bridewealth, usually gongs, large ceramic jars and jewellery, to be paid by the man's parents to the parents of his future wife. In this, the father of the bride-to-be has the final say. Once the date of the formal engagement (mupogong) is agreed upon, the young man must perform brideservice (jandian) and work for his future parents-in-law. Post-nuptial residence is normally uxorilocal (in the home of the bride) unless the parents of the husband have no daughters. In such a case, the married couple may periodically shift residence between their respective natal households. When the youngest daughter in a family marries, however, uxorilocal residence is a permanent arrangement and she and her husband inherit the house after the death of her parents (Lyman, 1990/1991, pp. 124128).

The traditional Makiang belief system acknowledges the existence of God who has the title of Minamaal ("the Creator") and the Personal Name of Kinoringan ("God most high"). It also differentiates between $a s u n d u^{\prime}$ or good celestial beings, and manuli or mainat that are evil spirits on the earth. Like other Paitanic peoples, most of Sabah's Dusunic and some Murutic societies, the Makiang believe that a human being has seven spirits. The Makiang refer to the large spirit of a human being that resides in the heart as the hatod, while bosou are the six smaller spirits in the joints. Upon death, the hatod goes to the afterworld or Nabalu. The name Nabalu is also used also among many Dusunic and some Murutic peoples for the afterworld. Among those Dusunic cultures, it is regarded as a spiritual counterpart to the physical Mt. Kinabalu. Nabalu among the Makiang, however, is not associated with any topographical feature (PughKitingan, 2017c).

In former times, the traditional Makiang religion was headed by highly esteemed priestesses or babalian, who memorised and then recited the sacred rinait 
(long ritual poetry) during complex ritual ceremonies, and sacrificed animals (usually pigs) as atonement (sonsob) for human wrongdoing. Each of these women was said to have a mamiau or familiar spirit. Apart from the priestesses, Makiang society also included ordinary spirit mediums and healers who themselves were called mamiau. They were also said to be seers. These could be women or men, but each had a mamiau or familiar spirit for healing. They did not, however, memorise and recite the rinait nor perform sacrifices and complex rituals like the babalian (Pugh-Kitingan, 2017c).

Today, most Makiang in the Upper Kinabatangan area are Christians of the Anglican Church. The percentage of Muslims in the population increases in villages downstream. There are roughly equal numbers of Christians and Muslims in $\mathrm{Kg}$. Imbak, with more Muslims further downstream around the new township of Kota Kinabatangan and on to Bukit Garam. Other Christian denominations are also present further downstream.

\section{Makiang Vocal Music and Sama'-Bajau Influences}

Apart from the ritual chanting of rinait by babalian, the Makiang performed many traditional genres of secular vocal music. Most of these have declined due to inroads made by new entertainment media. The morunsai circulating dance with its spontaneous call-and-response singing, however, is still extant and is an important feature of muilug discussions.

\section{Sama'-Bajau Influences in Upriver Circulating Dancing Call-and-Response Genres}

The terms morunsai or barunsai are used among many Paitanic peoples to refer to genres of movement by a line of men and women circulating in an anticlockwise circle, in which the dancers sing extemporaneous call-and-response phrases. Among the Tombonuo/Sungai of northeastern Sabah, the largest Paitanic ethnic group, these genres are said to be of Bajau or Suluk origin (Regis, Pugh-Kitingan, \& John Baptist, 2003, p. 25).

Indeed, many Sama'-Bajau communities perform similarly named genres. The west coast Bajau of Kota Belud and Tuaran Districts perform runsai (often prefixed with the Malay ber- as berunsai; also spelled runsay) in which a line of men and a line of women, joined by a handheld cloth, circulate anticlockwise while calling out in extemporaneous alternating pantun-like verses called kallang. Headed by a senior matriarch, runsai is a form of indoors entertainment at social gatherings, especially wedding celebrations, that take place from midnight to morning inside the home or either the bride's family or that of the bridegroom. In Kota Belud and Tuaran, runsai is performed by middle-aged or elderly married people, using a poetic language that is said to be a mixture of West Coast Bajau and "Kagayan" or Mapun, a Sama' language from the Philippines. The kallang themes, determined by the matriarch, can impart a moral message, are often used for match-making or for courtship, sometimes jokingly 
ridicule the opposite sex, and may express anger and insult in a neutral context. As the performers approach a conclusion to an issue discussed back and forth in the kallang, the men rhythmically stamp their feet on the floor, before the matriarch introduces a new topic for debate. This west coast Bajau runsai is entertaining, and its kallang verses are quite humorous. It serves an important social function in traditional Bajau village life, by providing a vehicle for discussing sensitive issues in a neutral and nonthreatening context (Regis et al., 2003; Matusky \& Pugh-Kitingan, 2004).

It appears that runsai-type genres were performed among most Sama' cultures, including those of Semporna on the east coast, but many are no longer extant. Recent "Kagayan" or Jama Mapun immigrants from Cagayan de Sulu Island in the southern Philippines, however, are often hired to perform their lunsay for entertainment during wedding celebrations among the Iranun community of Kota Belud District. This lunsay genre is headed by an elderly man and woman, but includes mostly younger unmarried people. Performed on wooden boards laid on the ground under a tent outside, it has a very rapid pace, and both men and women stamp their feet (Regis et al., 2003, pp. 32-33).

\section{Morunsai}

The Makiang morunsai or barunsai may have developed through cultural diffusion from Sama'-Bajau communities on the east coast via the Ida'an, Bega'ak and Subpan, who are sub-groups of the ancient indigenous Ida'an language group which is distantly related to the Paitanic peoples. Its performance is very similar to the rumunsai of the Subpan of Kg. Sapugaya on the Segama River, Lahad Datu, who have also adopted some musical genres from the east coastal Bajau and Suluk. While the Makiang morunsai can be used for entertainment in some contexts, it is primarily the traditional vehicle for negotiation during muilug discussions prior to the mupogong or engagement ceremonies.

Those involved in the morunsai include the parents of the potential bride and groom, a go-between, and other close kin. Members are not divided by gender, unlike Sama'-Bajau runsai. They form a circle in which each person links their little fingers with those of the people on either side. Everyone faces into the circle. The pace is very slow. Each person steps slightly into the circle, then out, normally using a pattern of right foot $\rightarrow>$ left foot (in) slight pause together, left foot $\rightarrow>$ right foot (out), or for some individuals left foot $->$ right foot (in) slight pause together, right foot-left foot (out). This produces slight swaying motion as the circle moves anti-clockwise. The slow circular movement of dancers facing into the circle with little fingers linked and consequent swaying of the arms is very similar to the Subpan rumunsai.

Extemporaneous verses in the Makiang dialect, often described as pantun, are sung slowly and loudly without distinct rhythms and in a melismatic style. As noted previously, each individual tends to use their own pitch arrangement, regardless of the others in the group. This can create somewhat discordant layers of overlapping 
sounds for the listener (Regis et al., 2003, p. 34). There may be long pauses punctuated by short comments and laughter. The pantun articulated during the morunsai thus constitutes a musical discussion in which individuals melodically expresses their opinions.

The musical patterns of a short excerpt from a morunsai performed at $\mathrm{Kg}$. Imbak in Tongod District, are transcribed in Figure 1. Throughout the complete performance, much of the melodic material was pentatonic without semitones. Participants did not always adhere to the basic pitch arrangement, however, and some tended to sing flat in relation to others. This can be seen in the short transcription here, which starts with a line sung by one man. One woman then responds, overlapping with his line, but her pitches sound a semitone flat in relation to his (and also in relation to a previous lines that are not shown here). As she proceeds, other women join in and pitches are then raised around a semitone. The man resumes singing towards the end of the women's line.

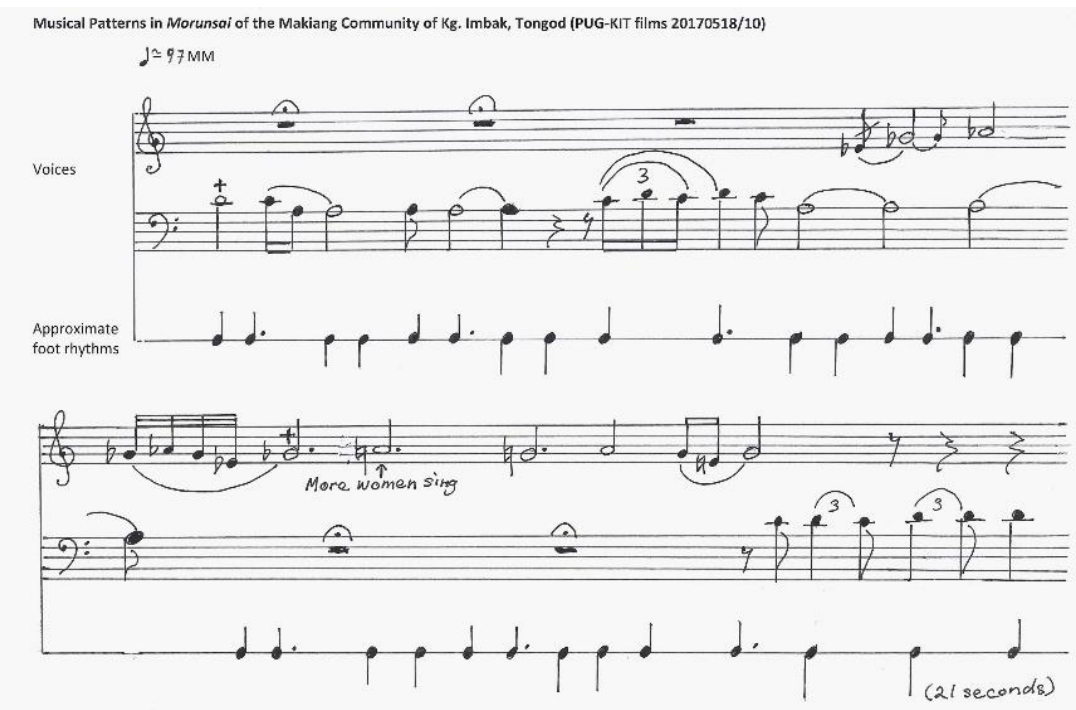

Figure 1: A short excerpt of Makiang morunsai from Kg. Imbak, Tongod, in 2017 (Source: Jacqueline Pugh-Kitingan)

The approximate rhythmic patterns produced by the dancers' foot movements are transcribed below their sung melodies. While upward stems indicate movements into the circle and downward stems show movements out; the actual footsteps are not transcribed. This transcription merely outlines their pace and general rhythm; the singing is not fixed to these basic foot rhythms.

There is no rhythmic foot stamping in the Makiang morunsai, unlike the Sama'Bajau genres. The circle moves around slowly as the suitability of the potential match is discussed. If the father of the girl disagrees to the marriage, however, he will stamp 
his foot once. Then, the whole morunsai and muilug ends. There is no further discussion, and the engagement and wedding will not proceed.

If, however, all issues concerning the marriage are discussed and resolved through the pantun and everyone participating in the morunsai agrees to the union, all the dancers will stamp their feet in unison. This concludes the morunsai and the engagement followed later by the wedding can proceed.

The morunsai thus serves an important function in the muilug. It provides a traditional performative process through which issues concerning the proposed marriage can be discussed and disagreements can be expressed without causing offence. If the father of the girl indicates his disapproval of the suitor or his family by stamping his foot, there is no argument. His wishes must be respected. If everyone agrees to the match, however, the terms of the engagement, bridewealth components, and dates for the lengthy wedding celebrations can be determined.

\section{Makiang Instrumental Music and Sama'-Bajau Influences}

The Makiang formerly played several types of traditional solo secular instruments for entertainment, including a mouthorgan resembling the sompoton of the Kadazan Dusun of Tambunan District that was traded into the Tangara Murut community of the remote Upper Kinabatangan River and from there into Kalabuan, Makiang and other Paitanic communities in the area (Pugh-Kitingan, 2011). Like most Makiang secular vocal music, solo instrumental genres have declined in recent years with the advent of new entertainment media. The Makiang gabang xylophone, however, is still extant and is often played as a solo instrument.

For group instrumental music, the Makiang have two main ensembles: the sampasang no kulintangan that consists of a kulintangan (a set of small kettle gongs struck with pairs of beaters) and hanging gongs, and the sampasang no gabang that features a gabang and wooden slit gongs or kantung. Sometimes, these are mixed-the gabang might be played with hanging gongs instead of the kulintangan, or one or two slit gongs may be included in the sampasang no kulintangan. These ensembles show influence from east coastal gong ensembles.

\section{Influence of Sama'-Bajau Idiophones on Upriver Ensembles}

In Sabah, the kulintangan is not found in the large ensembles of hanging gongs played among Dusunic and Murutic peoples, unless the people have access to the coast. The Labuk-Kinabatangan Dusun, the Tidung, all Paitanic peoples, and the Ida'an/Bega'ak/Subpan of eastern Sabah, however, all have river access to the coast and hence, all have the kulintangan in their ensembles. Moreover, their gong ensembles are similar to the tagunggu' ensemble of the east coast Bajau (Pugh-Kitingan, 2019; Pugh-Kitingan \& John Baptist, 2005). 
This Sama'-Bajau tagunggu' consists of the kulintangan, two or three large hanging gongs called agong or agung (tawag types), and the brass-bodied tambol drum. Sometimes, a babandil or bandil (smaller sanang-type or large thin brass tagung-type) may also be included. A skilled virtuoso plays the kulintangan, usually accompanied by an assistant who strikes the highest-pitched kettle gong with a single beater. The kulintangan leads the ensemble, while the other instruments have supporting roles. Both men and women can play these instruments. The Sama'-Bajau tagunggu' repertoire consists of up to twelve or more pieces or titik, each identified by its rhythm and melodic outline played on the kulintangan.

Inland communities living up the eastern rivers, such as the Makiang, have developed their repertoires that tend to have less titik than those of coastal communities. The drum also occurs less in ensembles from further upstream and into the remote interior.

As shown previously, the Makiang gabang xylophone probably developed from the gabbang of east coast Sama'-Bajau and Suluk communities (Pugh-Kitingan, 2017d). Indeed, the Bajau gabbang itself is said to have originated from that of the Suluk (Tausug) of the southern Philippines. It consists of up to 17 keys of gradated lengths made from either nibung palm or bamboo, on an ornate steep-sided asymmetrical frame or papagan gabbang. The keys are struck with two carved beaters or titik. On this Bajau gabbang, the highest pitched key lies near the performer's left hand, and the lowest near the right hand (for a right-handed performer). Gabbang performance is a highly esteemed skill in Sama'-Bajau society. The instrument is played solo by both men and women in both important social and ritual contexts, and has its own repertoire of titik (Pugh-Kitingan, 2010).

\section{Gabang and Sampasang no Gabang}

The Makiang gabang, made from tombirog wood, is much heavier than the Bajau gabbang. It consists of nine or ten wooden keys, sitting on a low wooden frame or papagan. Its keys are struck with two carved beaters called lilisag or tititik. Unlike the Bajau gabbang, the highest pitched key of the gabang lies near the performer's right hand and the lowest pitched one is near the left hand (Pugh-Kitingan, 2017d).

The sampasang no gabang consists of a gabang and two or three wooden kantung slit gongs (Plate 1), but can also include hanging gongs (agung) and one or two small bamboo tolutuk slit gongs. The kantung are struck with papankul or beaters made from tagas wood. Their role in the music is essentially the same as that of two or three agung that are played in the Makiang sampasang no kulintangan and the agong in the Bajau tagunggu'. While the kantung appear to be a Makiang innovation, it appears that the sampasang no gabang may have developed earlier on among the Makiang upstream in imitation of brass ensembles further downstream that include the metal kulintangan and hanging gongs. Ian Baxter observed a metal-keyed gabang played with two tolutuk and galu rice pounders at Kg. Talibu (Baxter 2017, pp. 287-288, 342). 
The gabang can play the kulintangan pieces together with the hanging gongs, especially if no kulintangan is available, but it also has its own repertoire. Table 1 shows the repertoire of the Makiang sampasang no gabang from Bukit Garam and Kota Kinabatangan Town, in Kinabatangan District, that is quite different from the sampasang no kulintangan repertoire from the same area (Table 4).

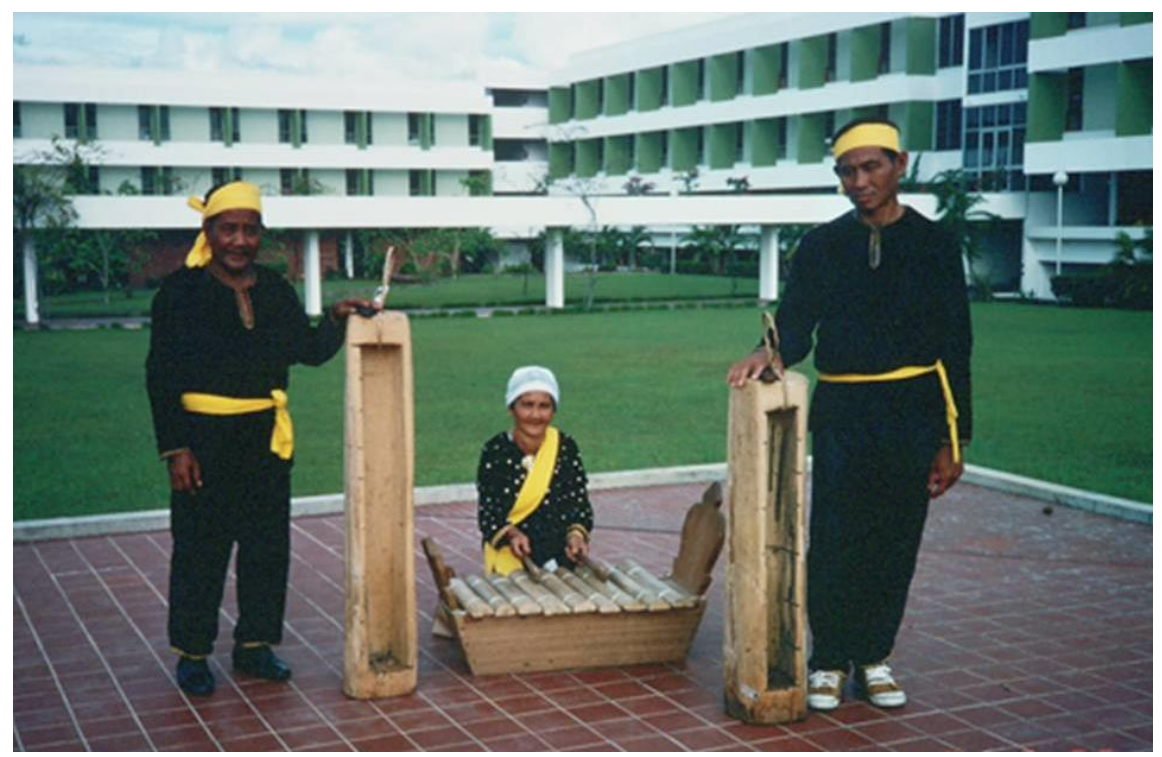

Plate 1: Basic Makiang sampasang no gabang ensemble, from Bukit Garam and Kota Kinabatangan, Kinabatangan District (Sources: Fieldwork 1989; Pugh-Kitingan [2017d, p. 94].)

Table 1: Repertoire of Titik for the Makiang sampasang no gabang, Bukit Garam and Kota Kinabatangan

\begin{tabular}{|c|l|l|}
\hline & Titik Name & Purpose \\
\hline 1. & Titikas & To accompany silat martial arts and also titikas dance \\
\hline 2. & Titik Lumambai & To accompany lumambai dance \\
\hline 3. & Titik Mangalai & To accompany mangalai dance \\
\hline
\end{tabular}

Sources: Fieldwork, 1989, 1999; Pugh-Kitingan (2017d, p. 95).

Here, the repertoire of the sampasang no gabang contains three titik, each of which accompanies different genres of dancing. The titik called Titikas also accompanies traditional martial arts, generally known as silat.

\section{Sampasang no Kulintangan}


Like the Bajau tagunggu', the Makiang sampasang no kulintangan contains the kulintangan and two or three large hanging gongs. The Makiang set may also include other instruments such as a small hanging sanang type gong called babandil or bandil, a wooden slit gong or kantung, and the small bamboo slit gong tolutuk. In villages further upstream, gong sets tend to contain less instruments, often with just the kulintangan and gongs.

The sampasang no kulintangan from $\mathrm{Kg}$. Imbak is an example (Plate 2). It consists of the kulintangan, three large hanging gongs called agung, and the smaller babandil. Of the three large gongs, two are played together by one performer and hence are collectively called uliyon agung or ulion agung, while the third is played separately by a third performer and hence is named agung tunggal. The terms babandil and agung or agong are used for certain types of gongs by many maritime peoples, such as the Sama'-Bajau, as well as among the Ida' an, Bega'ak and Subpan further inland.

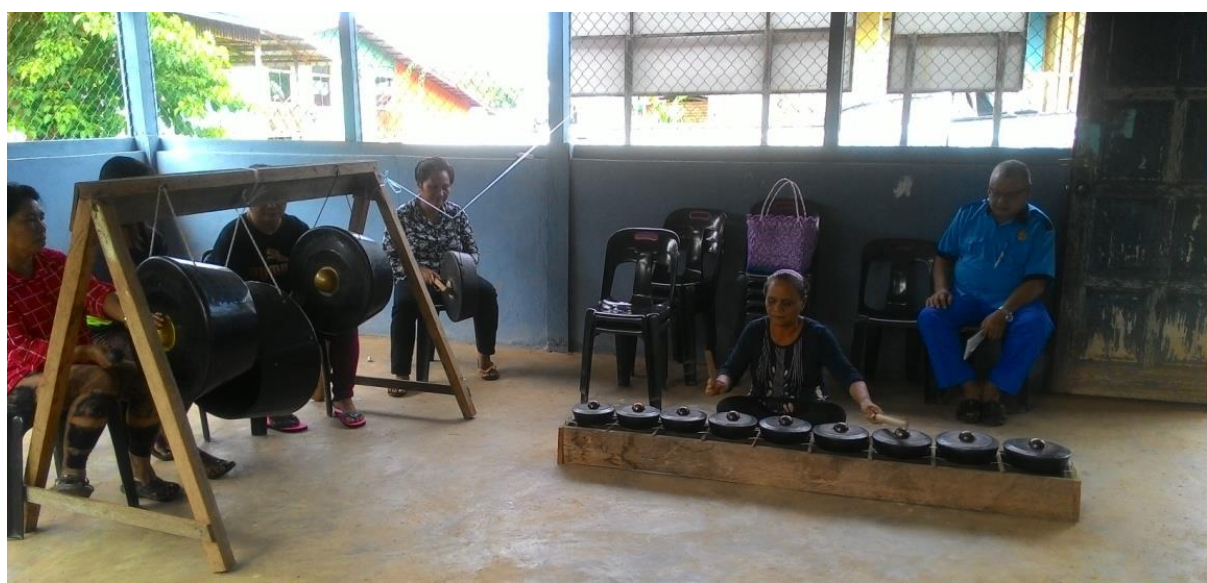

Plate 2: The Makiang sampasang no kulintangan of Kg. Imbak, Tongod District, with (from right to left) kulintangan, babandil, two uliyon agung, and agung tunggal (Source: Fieldwork 2017.)

Among the West Coast Bajau, for example, two babandil are played in the kurikuriyan beritik gong set from Kota Belud District, while those from of Putatan District include one bandil in their so-called kulintangan ensemble. These terms on the west coast are derived from the Iranun name bebendir for the same small gong, two of which are played in their kulintang ensemble (Pugh-Kitingan, 2004, pp. 154-161, 112-116, 118119, 171-175; 2017a; 2017b). As mentioned above, the Bajau Kubang of Semporna use the term babandil or bandil for a large thin brass tagung-type gong that is sometimes included in their tagunggu'.

Makiang repertoires may vary in number and names of titik according to village location. The repertoire of the Makiang sampasang no kulintangan ensemble 
from $\mathrm{Kg}$. Talibu upstream in Tongod District, for example, contains three main titik (Table 2). A fourth titik called Titipak is played in $\mathrm{Kg}$. Talibu with the gabang instead of the kulintangan, and other instruments in the sampasang no gabang together with two galu rice pounders that are struck against a length of bamboo. This piece is often performed when the married couple sit together on the bridal dias, but nowadays is used to accompany staged dancing by women at harvest festivals (Baxter, 2017, p. 293).

Table 2: Repertoire for the Makiang sampasang no kulintangan ensemble from Kg. Talibu, Tongod

\begin{tabular}{|c|c|c|}
\hline Context & Titik Name & Details/Purpose \\
\hline \multicolumn{3}{|l|}{$\begin{array}{l}\text { Wedding } \\
\text { celebrations }\end{array}$} \\
\hline 1. & Manglisiu & $\begin{array}{l}\text { Played when the bridegroom arrives at the bride's } \\
\text { house }\end{array}$ \\
\hline 2. & Muinakot & $\begin{array}{l}\text { Played when the couple sit together on the bridal } \\
\text { dais }\end{array}$ \\
\hline \multicolumn{3}{|l|}{$\begin{array}{l}\text { Harvest } \\
\text { celebrations }\end{array}$} \\
\hline 3. & Mangukai & $\begin{array}{l}\text { Played during village celebrations after the rice } \\
\text { harvest }\end{array}$ \\
\hline
\end{tabular}

Source: Baxter (2017, p. 293).

By contrast, the repertoire of the Makiang sampasang no kulintangan in Kg. Imbak, Tongkod consists of five titik (Table 3). This village is located roughly half way between Kg. Talibu, Tongod upstream, and Bukit Garam, Kinabatangan downstream.

Table 3: Repertoire of Titik for the Makiang Sampasang no Kulintangan from Kg. Imbak, Tongod

\begin{tabular}{|l|l|l|}
\hline Context & Titik Name & Details/Purpose \\
\hline $\begin{array}{l}\text { Wedding } \\
\text { celebrations }\end{array}$ & & \\
\hline 1. & Manulou & $\begin{array}{l}\text { Introduction - played prior to the arrival of the } \\
\text { bridegroom }\end{array}$ \\
\hline 2. & Minakod & $\begin{array}{l}\text { Played when the bridegroom arrives and the bride's } \\
\text { home }\end{array}$ \\
\hline 3. & Momouabi & $\begin{array}{l}\text { Played when the couple sit together on the bridal } \\
\text { dais }\end{array}$ \\
\hline 4. & Mangalisiu & $\begin{array}{l}\text { Played as a send-off when the couple visit the } \\
\text { groom's home }\end{array}$ \\
\hline $\begin{array}{l}\text { Other } \\
\text { celebrations }\end{array}$ & & \\
\hline
\end{tabular}




\begin{tabular}{|r|l|l|}
\hline 5. & Titikas & $\begin{array}{l}\text { To accompany silat performances, and also the } \\
\text { titikas dance }\end{array}$ \\
\hline
\end{tabular}

Source: Fieldwork, 2017.

The first four titik in this repertoire are played during wedding celebrations, while Titikas accompanies a dance of the same name, as well as silat martial arts performances. Normally, final wedding preparations in Makiang villages begin at least a week before the actual ceremony in the bride's house. During this time, there will be nightly kulintangan performances, until the full sampasang no kulintangan will be played a day or so before the wedding day. These nightly performances serve to announce the forthcoming wedding while providing an opportunity for the performers to practice (personal communication with Stuart Lyman, February 1995, at SIL Malaysia office, Kota Kinabalu).

The sampasang no kulintangan repertoire of the Makiang from Bukit Garam near Kota Kinabatangan, in Kinabatangan District (formerly part of Tongod District), contains more titik than those upstream (Table 4). Some of the titles clearly show Sama'-Bajau and Suluk origins, while others are also found among the Ida'an/Bega'ak/Subpan group who also have strong historical trade contacts with the Suluk and also Bajau peoples. This Makiang repertoire is played during wedding celebrations. Variations in similar sounding names of titik and meanings among the three villages may be due to differences in sub-dialect and personal pronunciation of individual musicians.

Table 4: Repertoire of Titik for the Makiang Sampasang no Kulintangan, Bukit Garam, Kinabatangan

\begin{tabular}{|r|l|l|}
\hline $\begin{array}{l}\text { Context } \\
\text { and other } \\
\text { events }\end{array}$ & Titik Name & Details/Purpose \\
\hline 1. & Tungkil & $\begin{array}{l}\text { Opening piece on celebratory occasions such as } \\
\text { weddings. }\end{array}$ \\
\hline 2. & Lubak-Lubak & $\begin{array}{l}\text { Medley of five pieces played to welcome guests. The } \\
\text { name is the same as that of a titik of Suluk origin in the } \\
\text { east coast Sama'-Bajau repertoire. It is also used for } \\
\text { some pieces in the Ida'an/Bega'ak repertoire }\end{array}$ \\
\hline 3. & $\begin{array}{l}\text { Manuk- } \\
\text { Manuk }\end{array}$ & $\begin{array}{l}\text { Formerly played by the riverside where a spear was } \\
\text { placed in the river as a welcome home for warriors } \\
\text { from battle. A titik of the same name is played by the } \\
\text { Ida'an and Subpan. }\end{array}$ \\
\hline 4. & $\begin{array}{l}\text { Apu' } \\
\text { Kalumbang }\end{array}$ & \begin{tabular}{l} 
Memories of the old folks (apu' = grandparent) \\
\hline
\end{tabular} \\
\hline
\end{tabular}




\begin{tabular}{|c|c|c|}
\hline 5. & Sago Tarupuk & Tarupuk = a type of bird \\
\hline 6. & $\begin{array}{l}\text { Linggam } \\
\text { Pulutan }\end{array}$ & \\
\hline 7. & $\begin{array}{l}\text { Mius } \\
\text { Minsarap }\end{array}$ & \\
\hline 8. & $\begin{array}{l}\text { Monogou } \\
\text { Pogong }\end{array}$ & $\begin{array}{l}\text { This name is also used for a titik in the repertoires of } \\
\text { the Ida'an, Bega'ak and Subpan. }\end{array}$ \\
\hline 9. & Mababa' & \\
\hline 10. & Minakod & $\begin{array}{l}\text { Titik for welcoming the bridegroom (minakod = } \\
\text { bridegroom) }\end{array}$ \\
\hline 11. & Kagayan & $\begin{array}{l}\text { This name refers to Jama Mapun people, a Sama' } \\
\text { group from Kagayan do Sulu Island, and may indicate } \\
\text { its origin. } \\
\text { A piece of the same name also occurs in the repertoire } \\
\text { of the Abai Sungai, a Paitanic group situated not far } \\
\text { from the mouth of the Kinabatangan in Sandakan } \\
\text { District (see Baxter [2017, pp. 144, 185-199]). }\end{array}$ \\
\hline
\end{tabular}

Source: Fieldwork, 1999.

The basic structure of Makiang sampasang no kulintangan music is somewhat similar to Bajau tagunggu' performance and the music of other similar ensembles, in that the kulintangan melody is of primary importance and is supported by the other instruments, but without the rapid beating of the tambol drum of the Sama'-Bajau ensemble. As among the Bajau and most other kulintangan-using groups, the Makiang kulintangan player is a virtuoso who knows all the pieces in the repertoire. She or he, however, is not usually accompanied by an assistant on the instrument.

An example of Makiang gong ensemble music is the piece Titikas from $\mathrm{Kg}$. Imbak, Tongod (Figure 2). This is the same titik as that played by the sampasang no gabang of Bukit Garam and Kg. Muhibah, Kota Kinabatangan that was discussed previously (Pugh-Kitingan, 2017d, pp. 94-95). Although the tunings of the kulintangan and hanging gongs (Figure 3) differ from those of the wooden $\mathrm{Kg}$. Muhibah idiophones, the distinctive rhythmic patterns of the titik in each measure, with the rising semiquaver-like motif followed by the high falling figure of a quaver and two semiquavers, are essentially the same. Throughout the piece, the melody moves motif by motif down the kulintangan then slowly rises back up to the higher-pitched kettles. 


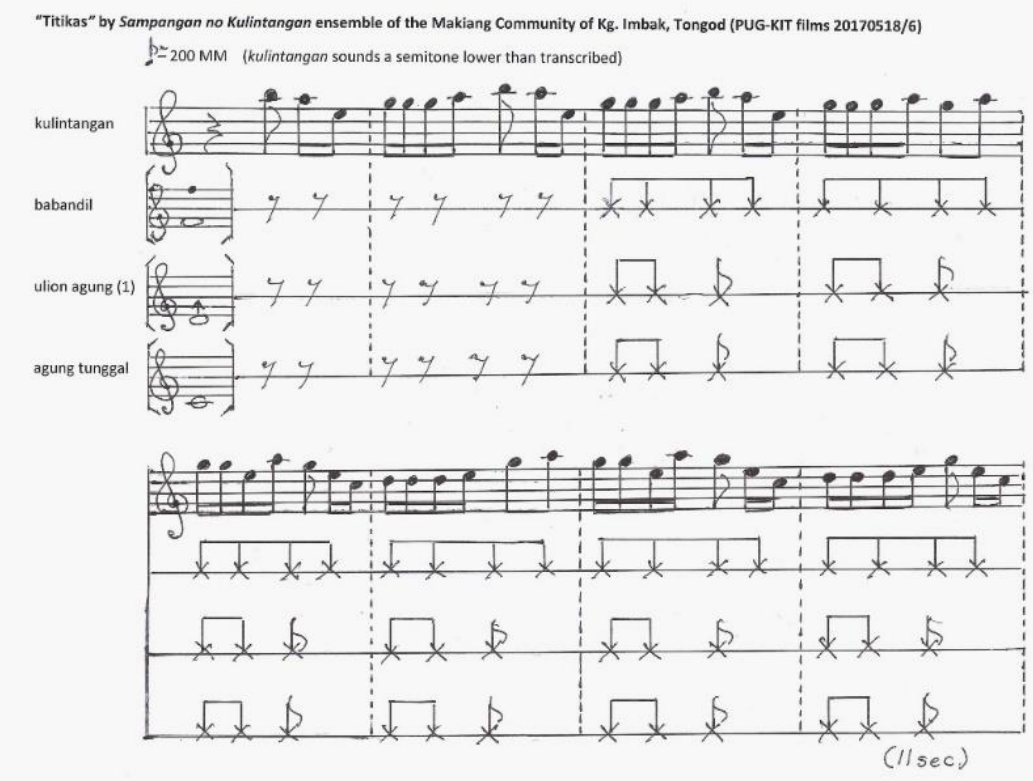

Figure 2: Excerpt of from the start of Titik Titikas from Kg. Imbak, Tongod (Source: Jacqueline Pugh-Kitingan.)

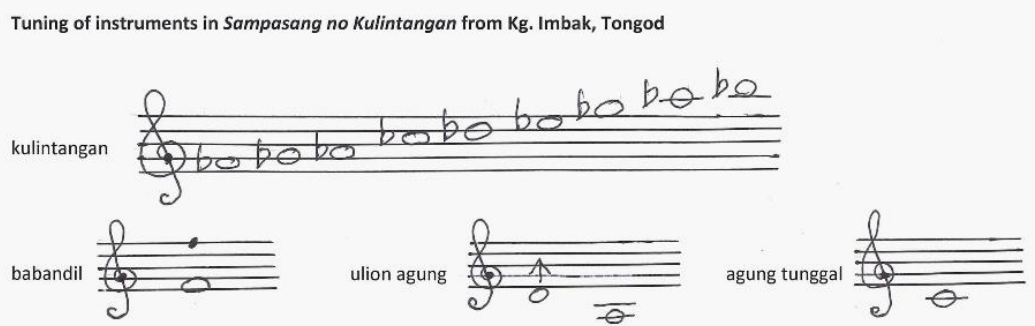

Figure 3: Tunings instruments in the Sampasang no Kulintangan from Kg. Imbak, Tongod (Source: Jacqueline Pugh-Kitingan.)

In this piece, all the hanging gongs accompany the kulintangan, except for the deeper sounding agung in the uliyon agung pair. The higher-pitched agung and the agung tunggal are tuned a whole tone apart like the two wooden kantung slit gongs in the Kota Kinabatangan sampasang no gabang. Their synchronous rhythmic patterns, however, are simpler, due to the more cumbersome movements involved in beating a large gong with a heavy mallet compared to hitting a kantung with a smaller wooden beater. 


\section{Conclusions}

It is clear that cultural convergence due to riverine trade with east coastal communities, which has occurred among various peoples living along the Kinabatangan River, has also affected Makiang music. Elements of Sama'-Bajau and also Suluk music can be seen in the names and types of instruments, as well as some names of Makiang musical pieces. Sama'-Bajau influences can also be traced in the morunsai or barunsai circulating dancing verse debate.

The name morunsai recalls the Sama'-Bajau terms runsai (or runsay) and lunsay. Its movement is anti-clockwise, and it involves the loud singing of extemporaneous alternating pantun-like verses back and forth between men and women in the group.

But morunsai is also different from the Sama'-Bajau runsai and boisterous lunsay that are today practiced in Sabah. It is consistently very slow throughout a performance and does not involve foot stamping, except as a final conclusion. Men and women are not separated according to gender in morunsai. Musically, morunsai does not adhere to strict melodic and rhythmic formulae as in the Sama'-Bajau genres. The musical lines are sung back and forth in free rhythm, with melodic material determined by each individual performer. In this, the Makiang morunsai is very similar to the Supban (Ida'an) rumunsai. It appears very likely that these genres have developed over time from the diffusion and adaptation of Sama'-Bajau runsai types among the Subpan, as well as Makiang and other Paitanic music-cultures.

The Makiang xylophone or gabang is said to have originated from the Suluk and Sama'-Bajau gabbang. Over time, the gabbang has become diffused into musiccultures further upstream as the gabang. This has resulted in structural transformations in the instrument, due to changes in ecology and available natural materials from a coastal environment to the interior. The wooden kantung slit gongs, however, appear to be a local innovation. The sampasang no gabang ensemble of gabang and two or three kantung has its own repertoire, although it can be used to play pieces from the sampasang no kulitangan repertoire.

The kulintangan as well as larger hanging gongs, has also been traded upriver from the coast, and the sampasang no kulintangan is similar to the Sama'-Bajau tagunggu' but without the tambol drum. As shown previously, interior Murutic and Dusunic ensembles that do not have the kulintangan consist of many hanging gongs, and each instrument has an equal role with the others in producing the rich sound texture of the particular colotomic music. Where the kulintangan is played with hanging gongs in ensembles, however, it assumes a leading melodic role with the other instruments providing supporting parts. It is not known what kinds of ensembles were played by Upper Kinabatangan peoples in ancient times, but the introduction of the kulintangan would have resulted in major creative transformations, allowing for a diversity of musical pieces produced with ensembles of comparatively less instruments than other interior sets. 
Musical pieces in a kulintangan repertoire are denoted by the term titik or "beat", a word also used similarly among coastal and maritime communities. Among the Makiang, repertoires from downstream contain far greater numbers of titik than those upstream, and the titles of some indicate that they originate the Ida'an/Bega'ak/Subpan further downstream, as well as from Sama'-Bajau and Suluk music-cultures on the coast. This richness of downstream Makiang repertoire thus points to the origins of the sampasang no kulintangan and its music among coastal and maritime peoples.

Thus, cultural convergence due to trade connections with the Sama'-Bajau and other coastal communities has affected musical cultures further upstream, including that of the Makiang. This is seen not only in the diffusion of traits such as musical terms and single objects like the gabang, but in major genres such as morunsai, and the sampasang no kulintangan ensemble, its performance practice and music. Over time, these elements have been adapted to suit Makiang society and environment, resulting in the development of a distinctive musical culture.

\section{Acknowledgements}

I wish to acknowledge En. Ayub Imbau and his wife and family of Bukit Garam and Kg. Muhibah, Kota Kinabatangan, Sabah, who first introduced me to Makiang music in 1989, and who in 1999 performed for us in the project Kulintang Music and 'Malay' Dance Traditions of North Borneo and the Philippines. This project was funded by a SEASREP Regional Collaboration Grant, and was jointly headed by Prof. Dr. Mohd Anis Md. Nor of the University of Malaya and Dr. Felicidad Prudente of the University of the Philippines. My recent fieldwork among the Makiang in 2017 was funded by Sabah Foundation and Petronas under the ICCA (Imbak Canyon Conservation Area) research project. My thanks go to Dr. Paul Porodong, Head of the ICCA Social Sciences Working Group, and Madam Pauline Yong Pau Lin who accompanied me in the field. I also acknowledge KK Samion, the Village Headman of Kg. Imbak, who arranged our recording and interview sessions, and the sampasang no kulintangan group Imbak Boleh, headed by Puan Pinoi, the village midwife, who is also an expert kulintangan player. My thanks also go the staff of the Sabah Forestry Department who graciously provided our accommodation. I also want to acknowledge Stuart and Adele Lyman, Jack and Carol Spitzack, and Wayne and Julie King who over the years imparted to me much knowledge about the Paitanic peoples of Sabah. 


\section{References}

Baxter, I. S. (2017). Kulintangan Music along the Kinabatangan River: Instruments, Repertoire and Music Structure. Ph.D. thesis, Faculty of Humanities, Arts and Heritage, Universiti Malaysia Sabah, Kota Kinabalu, Malaysia.

Kartomi, M. J. (2008). Preface. In M. J. Kartomi \& S. Blum (Eds.). Music-Cultures in Contact: Convergences and Collisions (pp. ix-xiii). New York: Routledge. (Original work published 1994)

King, J. K. (1997). The Paitanic Language Family. In J. K. King \& J. W. King (Eds.), Languages of Sabah: A Survey Report (pp. 139-153). Canberra: Research School of Pacific Studies, Australian National University. (Original work published 1984)

Lyman, S. T. (1991). The Makiang. In S. G. Lingenfelter (Ed.), Social Organisation of Sabah Societies: Studies from six societies: Bonggi, Ida'an, Lotud, Makiang, Tagal, Timugon (pp. 111-132). Kota Kinabalu: Sabah Museum and State Archives Department. (Original work published 1990)

Malaysia: Sabah. (2016). Ethnologue. Retrieved from http://www.ethnologue.com Matusky, P., \& Pugh-Kitingan, J. (2004). Pantun and verse debates. In Ghulam-Sarwar Yousof (Ed.), The Encyclopedia of Malaysia, Volume 8: Performing Arts (pp. 20-21). Kuala Lumpur: Editions Didier Millet Sdn. Bhd.

Pallesen, K. (1985). Culture Contact and Language Convergence. Manila: Linguistic Society of the Philippines.

Pugh-Kitingan, J. (2004). Selected Papers on Music in Sabah. Kota Kinabalu: Kadazandusun Chair, Universiti Malaysia Sabah.

Pugh-Kitingan, J. (2010). The Gabbang and Its Music Among the Bajau Kubang of Semporna, Sabah, Malaysia. Journal of Maritime Geopolitics and Culture, 1(1), 123-140.

Pugh-Kitingan, J. (2011). A Preliminary Comparison of the Kadazandusun Sompoton from Tambunan and the Tangara Murut Kulundi of Inarad, Upper Kinabatangan. Gendang Alam, 2, 67-82.

Pugh-Kitingan, J. (2017a). Bajau Diaspora and Musical Diffusion: West Coast Bajau Influence on the Mojumbak of the Lotud Dusun of Tuaran, Sabah. In Mohd Anis Md. Nor (Ed.), Perspectives on Bajau/Sama' Diaspora. Kota Kinabalu: Department of Sabah Museum.

Pugh-Kitingan, J. (2017b). Chasing a Tune: Andu-Andu in Gong Ensemble Repertoires among Sabah's West Coast Bajau, Iranun and Dusun Tindal. In Mohd Anis Md. Nor (Ed.), Proceedings of the $2^{\text {nd }}$ International Conference on Bajau Sama' Diaspora and Maritime Southeast Asian Cultures. Kuala Lumpur: NusPARC (Nusantara Performing Arts Research Centre).

Pugh-Kitingan, J. (2017c, 4-5 December). Preliminary Documentation of Intangible Cultural Heritage in Villages Near Imbak Canyon Conservation Area: Kampung Imbak. Report presented at ICCA Batu Timbang Scientific 
Expedition and Seminar \& Launching of ICCA Strategic Management Plan 2014-2023, Tun Hamdan Theater, Menara Tun Mustapha, Kota Kinabalu, Malaysia.

Pugh-Kitingan, J. (2017d). From Gabbang to Gabang: The Diffusion and Transformation of a Philippine Xylophone among Indigenous Paitanic Communities of Sabah, Malaysia. Borneo Research Journal, 1, 106-117.

Pugh-Kitingan, J. (2019). Gongs, Gong Ensembles, and Gong Music in Sabah as Markers of Indigeneity, Diffusion and Diaspora. In Ismail Ibrahim, Mat Zin Mat Kib, \& Sim Chee Cheang (Eds.), Borneo dalam Kepelbagaian Perspektif (pp. 301-320). Kota Kinabalu: Penerbit Universiti Malaysia Sabah.

Pugh-Kitingan, J., \& John Baptist, J. (2005). From Coastal Communities to Interior Peoples-The Dispersion and Diffusion of the Kulintangan in Sabah. In Abdul Halim Ali (Ed.), Borneo - Kalimantan 2005: Transformasi Sosial MasyarakatMasyarakat di Daerah Pesisir Borneo-Kalimantan. Prosiding Konferensi Antara Universiti di Borneo - Kalimantan Ke-1 (pp.1-12). Kota Samarahan: Institut Pengajian Asia Timur, Universiti Malaysia Sarawak.

Regis, P., Pugh-Kitingan, J., \& John Baptist, J. (2003). Berunsai: Meeting, Matchmaking and Music. Tirai Panggung: Jurnal Seni Persembahan, 6, 23-37.

Vaz, J., \& Payne, J. (1998). The Kinabatangan Floodplain: An Introduction. Kota Kinabalu: WWF Malaysia in association with Ministry of Culture, Environment and Tourism, Sabah, and GTZ the German Agency for Technical Cooperation. (Original work published 1997) 